Mona Hjønnevåg Joof, konsulent/klinisk spesialist i sykepleie, Kompetansesenter for import- og tropesykdommer, Ullevål universitetssykehus.

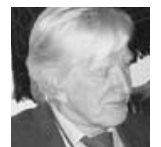

Bjørn Myrvang, overlege/ professor, Kompetansesenter for import- og tropesykdommer, Ullevål universitetssykehus.

\section{Man må være ferdig utdannet sykepleier og ha minst to års relevant arbeidserfaring for å kunne dra faglig nytte av undervisningen på de fleste kursene.}

\author{
Les mer og finn \\ litteraturhenvisninger på \\ www.sykepleien.no \\ Søkeord: \\ Tropemedisin \\ Flyktninger \\ Katastrofer \\ Samfunnshelse
}

\title{
Kurs i tropemedisin
}

\author{
Mange sykepleiere ønsker å øke sine kunnskaper \\ om tropemedisin og helseproblemer i ressursfattige land.
}

I Norge finnes det knapt kurs for sykepleiere i dette fagområdet. I utlandet er det imidlertid en jungel av kurs og utdanningsinstitusjoner å velge mellom, noe som kan giøre det vanskelig å velge kurs. De viktigste faktorene når man skal velge vil for de fleste være kursets innhold, opplegg og varighet. Kursdeltakelse i utlandet vil også innebære betydelige kostnader som de færreste kan dekke selv, i form av kursavgift, skolemateriell, reise og opphold.

Vi ønsker at denne artikkelen skal gjøre det lettere for hver enkelt å velge det kurset som passer. Artikkelen tar også for seg økonomisk støtte.

\section{Hva finnes av kurs?}

Jakten på et kurs vil for mange starte på Internett, men det kan ta tid å orientere seg i den omfattende kursmengden som finnes. Nettstedene healthtraining.org (1) og tropEd.org (2) gir en god oversikt. Vi fant 264 kurs innen fagområdet tropemedisin. Oversiktene omfatter kurs i enkeltemner, omfattende fleremnekurs, kurs som ledd i mastergrads- og doktorgradsutdanninger, konferanser, sommerskoler og fjernundervisning. Kursene varer fra noen dager til flere år, og arrangeres i mange deler av verden.

Artikkelen vil i hovedsak ta for seg kurs som varer i cirka tre måneder. I løpet av denne tiden vil man kunne tilegne seg solide og verdifulle kunnskaper som gir et godt grunnlag, enten man skal jobbe i Norge med importmedisinske problemstillinger eller i tropeområder og ressursfattige land.

\section{Oversikt over «tremåneders kurs»}

Blant de 264 kursene som finnes på de to nettstedene $(1,2)$, har vi funnet fram til ni årlige kurs som har en varighet på om lag tre måneder og som er omtrent like når det gjelder bredde og innhold (3-11). Kursene er ført opp i Tabell 1, som viser noen viktige kjennetegn ved hvert av kursene. Opplysningene i tabellen er basert på skolenes egne internettpresentasjoner, men disse kan være mangelfulle. Erfaringsmessig betyr derfor ikke manglende kryss i de ulike kategoriene nødvendigvis at temaet $i k k e$ tilbys, og det kan lønne seg å kontakte skolene direkte og be om en pålitelig oversikt, for eksempel en timeplan.

Åtte av de ni kursene vi har funnet fram til, arrangeres i europeiske land, det niende kurset foregår i Lima, Peru. Undervisningsspråket ved de fleste kurs er engelsk, men på kursene i Lyon i Frankrike, og Brescia i Italia, undervises det på henholdsvis fransk og italiensk $(3,4)$.

\section{Hva kjennetegner kursene?}

Selv om innholdet varierer noe, er nok ikke den faglige forskjellen mellom kursene særlig stor. Men de fleste kurs har sine særtrekk som kan være avgjørende for hva man velger.

De fleste av de ni kursene legger stor vekt på de sentrale emnene samfunnshelse og tropemedisin, selv om tilnærmingsmåtene varierer. Seks av kursene gir også praktisk laboratorieundervisning i parasittologi, mikrobiologi og entomologi. Her får man studere vektorer og parasitter på nært hold med lupe og mikroskop. Det avhenger selvsagt av hva slags interesser man har, men for mange vil det nok føles som en mangel at kursene i Lyon, Uppsala og Amsterdam ikke har laboratorieundervisning $(3,5,6)$.

Kursene i Lyon, Brescia, London, Liverpool og Lima er selvstendige tropemedisinkurs og dekker et bredt spekter av temaer, de fleste forskningsrelaterte $(3,4,7,8,9)$. Kurset i London er det eneste deltidskurset med undervisning en dag i uka i 19 uker. Kurset passer vel derfor ikke spesielt godt for norske sykepleiere, hvis man da ikke planlegger å utnytte London-oppholdet på annet vis. Mange norske sykepleiere har gått på kurs i Liverpool, og vært fornøyde med dette. Brescia og Lyon synes å ha færre temaer i kursene sine sammenlignet med de øvrige. Temaer som flyktninghelse og ernæring står blant annet ikke på programmet.

Kursene i Uppsala, Amsterdam, Basel og Berlin er modulkurs og inngår som et ledd i mastergradsutdanning $\mathrm{i}$ internasjonal helse $(5,6,10,11)$. Det innebærer at man som sykepleier kan delta på modulen som omfatter undervisning i tropemedisin. Kurs 


\begin{tabular}{|c|c|c|c|c|c|c|c|c|c|c|c|c|c|c|c|c|c|}
\hline Kurs & Skole & $\begin{array}{l}\text { Lengde } \\
\text { Semester-start }\end{array}$ & $\begin{array}{l}\text { Sted } \\
\text { Språk }\end{array}$ & 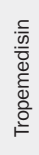 & 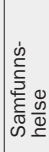 & 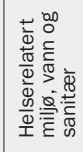 & 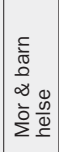 & 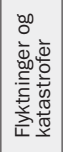 & 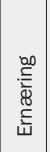 & 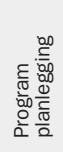 & 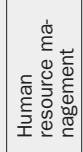 & 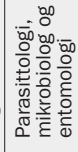 & 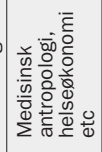 & 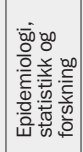 & 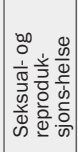 & 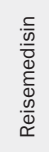 & Merknad \\
\hline $\begin{array}{l}\text { Diploma in Tropical } \\
\text { Medicine \& } \\
\text { Public Health }\end{array}$ & $\begin{array}{l}\text { Charité universitäts-medizin } \\
\text { Berlin, Humboldt University } \\
\text { and Free University Berlin }\end{array}$ & $\begin{array}{l}13 \frac{1}{1 / 2} \text { uke, fulltid } \\
\text { Mars \& } \\
\text { september }\end{array}$ & $\begin{array}{l}\text { Berlin, Tyskland } \\
\text { Engelsk }\end{array}$ & $x$ & $x$ & $x$ & $x$ & $x$ & $x$ & $x$ & $x$ & $x$ & $x$ & $x$ & $x$ & & $\begin{array}{l}\text { Modul } \\
\text { kurs i master- } \\
\text { grad utd. }\end{array}$ \\
\hline $\begin{array}{l}\text { Health care and } \\
\text { management in tropical } \\
\text { countries (HCMTC) }\end{array}$ & $\begin{array}{l}\text { Schweizerishes Tropen- } \\
\text { instituut, Basel }\end{array}$ & $\begin{array}{l}13 \text { uker, fulltid } \\
\text { Mars }\end{array}$ & $\begin{array}{l}\text { Basel, Sveits } \\
\text { Engelsk }\end{array}$ & $\mathrm{x}$ & $x$ & $\mathrm{x}$ & $\mathrm{x}$ & $\mathrm{x}$ & $x$ & $x$ & $\mathrm{x}$ & $x$ & $x$ & $x$ & $x$ & & $\begin{array}{l}\text { Modul } \\
\text { kurs i master- } \\
\text { grad utd. }\end{array}$ \\
\hline $\begin{array}{l}\text { Diploma in International } \\
\text { Community Health } \\
\text { Care (DICHC) }\end{array}$ & $\begin{array}{l}\text { Liverpool School of Tropical } \\
\text { Medicine (LSTM) }\end{array}$ & $\begin{array}{c}12 \text { uker, fulltid } \\
\text { April }\end{array}$ & $\begin{array}{l}\text { Liverpool, England } \\
\text { Engelsk }\end{array}$ & $\mathrm{x}$ & $x$ & $x$ & $x$ & $x$ & $x$ & $\mathrm{x}$ & $\mathrm{x}$ & $x$ & $x$ & $x$ & $x$ & & $\begin{array}{l}\text { Erstatter } \\
\text { CTCM\&H fra } \\
2009\end{array}$ \\
\hline International Health & $\begin{array}{l}\text { Uppsala universitetet - Internatio- } \\
\text { nal Child Health \& Nutrition Unit }\end{array}$ & $\begin{array}{l}\text { 9-10 uker } \\
\text { August }\end{array}$ & $\begin{array}{l}\text { Uppsala, Sverige } \\
\text { Engelsk }\end{array}$ & $x$ & $x$ & $x$ & $\mathrm{x}$ & $\mathrm{x}$ & $x$ & $\mathrm{x}$ & $x$ & & $x$ & $\mathrm{x}$ & $x$ & & $\begin{array}{l}\text { Modul kurs } \\
\text { i master- } \\
\text { grad utd. }\end{array}$ \\
\hline $\begin{array}{l}\text { Diploma in tropical } \\
\text { nursing }\end{array}$ & $\begin{array}{l}\text { London School of Hygiene \& } \\
\text { Tropical Medicine }\end{array}$ & $\begin{array}{c}19 \text { uker, deltid; } \\
1 \text { dag/uke } \\
\text { Februar \& september }\end{array}$ & $\begin{array}{l}\text { London, England } \\
\text { Engelsk }\end{array}$ & $x$ & $x$ & $x$ & $x$ & $x$ & $x$ & (x) & $x$ & $x$ & $x$ & & & & \\
\hline $\begin{array}{l}\text { Netherlands Course } \\
\text { in Tropical Medicine } \\
\text { and Hygiene (NTC) }\end{array}$ & $\begin{array}{l}\text { Koninklijk Instituut voor } \\
\text { de Tropen }\end{array}$ & $\begin{array}{l}3 \text { mnd. } \\
\text { Mars og september }\end{array}$ & $\begin{array}{c}\text { Amsterdam, Holland } \\
\text { Engelsk }\end{array}$ & $x$ & $x$ & $x$ & $x$ & & & $x$ & $x$ & & $x$ & $\mathrm{x}$ & $\mathrm{x}$ & & $\begin{array}{l}\text { Modul kurs } \\
\text { i master- } \\
\text { grad utd. }\end{array}$ \\
\hline $\begin{array}{l}\text { Post-Graduate Course in } \\
\text { Tropical Medicine and Inter- } \\
\text { national Health }\end{array}$ & $\begin{array}{l}\text { Università degli Studi } \\
\text { di Brescia }\end{array}$ & 3 mnd. Januar & $\begin{array}{l}\text { Brescia, Italia } \\
\text { Italiensk }\end{array}$ & $x$ & $x$ & & $x$ & & & $x$ & $x$ & $x$ & $x$ & $x$ & $x$ & & \\
\hline $\begin{array}{c}\text { The Gorgas Diploma } \\
\text { Course in Clinical Tropical } \\
\text { Medicine }\end{array}$ & $\begin{array}{l}\text { University of Alabama at } \\
\text { Birmingham, US }\end{array}$ & $\begin{array}{l}9 \text { uker, fulltid } \\
\text { Januar }\end{array}$ & $\begin{array}{l}\text { Lima, Peru } \\
\text { Engelsk }\end{array}$ & $\mathrm{x}$ & $(x)$ & $x$ & $x$ & $(\mathrm{x})$ & (x) & & & $x$ & & $x$ & $\mathrm{x}$ & $\mathrm{x}$ & $\begin{array}{l}\text { Primært } \\
\text { for leger }\end{array}$ \\
\hline $\begin{array}{l}\text { Pathologie Tropicale et } \\
\text { Santé Communautaire }\end{array}$ & $\begin{array}{l}\text { L'Association Medicale } \\
\text { Missionaire }\end{array}$ & $\begin{array}{l}3 \text { mnd. } \\
\text { September }\end{array}$ & $\begin{array}{l}\text { Lyon, Frankrike } \\
\text { Fransk }\end{array}$ & $\mathrm{x}$ & $\mathrm{x}$ & $x$ & $x$ & & & $x$ & $x$ & & $x$ & $\mathrm{x}$ & $x$ & $(\mathrm{x})$ & \\
\hline
\end{tabular}

Tabell 1: Oversikt over tremånders kurs i tropemedisin i utlandet.

som ledd i masterutdanning har en mer forskningsbasert tilnærming til tropemedisin/internasjonal helse enn de øvrige.

The Gorgas Diploma Course in Clinical Tropical Medicine (9) i Lima er det eneste kurset av de ni utvalgte som er lokalisert i et tropisk strøk. Dette er et kurs som primært er beregnet for leger, men unntaksvis kan sykepleiere også få plass på kurset.

Dette kurset har den fordelen at man får se mange pasienter med ulike tropesykdommer i løpet av de tre månedene. Lima-kurset har et omfattende innhold med blant annet reisemedisin og utflukter til Andesfjellene på programmet, men mangler visse temaer som finnes på andre kurs.

Flere norske leger har vært i Lima og anbefaler dette kurset.

\section{Passer kurset for meg?}

Man må være ferdig utdannet sykepleier og ha minst to års relevant arbeidserfaring for å kunne dra faglig nytte av undervisningen på de fleste kursene. Sykepleiere som jobber i ressursfattige land, gis vanligvis fortrinnsrett.

Alle kurs har et begrenset antall studieplasser, og på noen kurs, som «International Health» i Uppsala, blir mastergradsstudenter prioritert. Kurset i Lima har adgang for sykepleiere kun etter avtale, fordi det undervises med tanke på legers kompetanse.

Som nevnt innledningsvis finnes det en rekke andre kurs i tropeme- disin rundt omkring i verden. Disse faller utenfor denne oversikten fordi de ikke samsvarer med våre valgte kriterier for varighet, faglig innhold og så videre. På hjemmesiden til Kompetansesenter for import- og tropesykdommer ved Ullevål universitetssykehus (12), samt internettsidene vi nevnte innledningsvis, finner du en langt mer omfattende oversikt over kurs som tilbys verden over.

\section{Finansiering}

De samlede utgiftene til et tremåneders kurs beløper seg fort til 40-50.000 kroner, hvorav kursavgiften vil utgjøre hoveddelen. Statens lånekasse for utdanning (13) kan ofte løse en del av de finansielle problemene ved stipend/lån, og har de siste årene dekket kursavgiften med stipend, forutsatt at kurset ikke tilbys innenlands. Lånekassens regler for støtte til kursavgift, skolemateriell, reise, oppholds- og boutgifter revideres hvert år. En må derfor orientere seg om hva som er gjeldende regler på det tidspunktet man skal gjennomføre utdanningen.

De to nasjonale kompetansesentrene med spesialkompetanse innen fagfeltet; Kompetansesenter for import- og tropemedisin (12) og Kompetansesenteret for tropemedisin og importerte infeksjonssykdommer (14) ved henholdsvis Ullevål og Haukeland universitetssykehus, har de siste årene gitt samordnet støtte til aktuelle kandidater. Støtteordninger tilbys også fra andre instanser, og Legathåndboken (15) gir en bred oversikt. Mange arbeidsgivere vil også kunne tilby stipend eller permisjon med full eller delvis lønn. Det er eksempler på at arbeidsgivere har gitt delvis lønn under kurset mot at kursdeltakeren binder seg til å arbeide ved institusjonen i en viss periode etter gjennomført kurs.

\section{Klar til søknad}

$\mathrm{Vi}$ anbefaler at man først setter seg inn i hvilke tropemedisinske kurs som er tilgjengelige for sykepleiere, deretter bestemmer seg for hvor lang tid man ønsker å bruke på utdanningen og hvor i verden man ønsker å følge kurset. Vi håper at denne veiledningen kan være til hjelp slik at du kan velge det kurset som passer best for deg. Trenger du informasjon utover det som finnes i denne artikkelen, kan du søke på internettsidene (1-12), eller ta direkte kontakt med aktuelle læresteder og be om timeplaner og så videre. I tillegg vil man ofte få nyttig informasjon fra sykepleiere som har deltatt på kurs ved de ulike læresteder. Kompetansesenter for import- og tropesykdommer UUS har laget en oversikt over sykepleiere som de senere år har tatt tropemedisinsk etterutdanning, og som er villig til å bidra med opplysninger og råd til potensielle kursdeltakere. Finansieringen, som man bør ha i tankene på et tidlig tidspunkt, løser seg ofte ved hjelp av de ulike støtteordningene som finnes.

\section{LITTERATUR}

1. www.healthtraining.org

2. tropEd, www.troped.org

3. Pathologie Tropicale et Santé Com munautaire, L'Association Medical Missionnaire, Lyon, Frankrike, http://ammformation.org/programme4.htm

4. Post-Graduate Course in Tropical Medicine and International Health, Università degli Studi di Brescia, Italia, www.unibs.it

5. International Health, Uppsala universitetet, Sverige, www.kbh. uu.se/imch

6. Netherlands Course in Tropical Medicine and Hygiene, Koninklijk Instituut voor der Tropen, Amsterdam, Nederland, www.kit.nl/ development/ $\mathrm{html} / \mathrm{ntc}$.asp

7. Diploma in tropical nursing, London School of Hygiene and Tropical Medicine, England, www.Ishtm.ac.uk

8. Diploma Course in International Community Health Care, Liverpool School of Tropical Medicine, England, www.liv.ac.uk/lstm/learning_taching/post_grad/dipl_ichc.htm

9. The Gorgas Diploma Course in Clinical Tropical Medicine, University of Alabama at Birmingham, US, Gorgas Institute, Lima, Peru, www.gorgas. dom.uab.edu

10. Health care and management in tropical countries, Schweizerishes Tropeninstituut, Basel, Sveits, www. sti.ch/fileadmin/user_upload/Pdfs/ tnt/HCMTC_2008_courseinfo.pdf

11. Diploma in Tropical Medicine \& Public Health, Charité universitätsmedizin Berlin, Humbolt University and free University Berlin, Tyskland, www.internationalhealth.de

12. Kompetansesenter for import- og tropesykdommer, Ullevål universitetssykehus, http://tropesykdommer.ulleval.no

13. Lånekassen, www.lanekassen.no

14. Kompetansesenter for tropemedisin og importerte infeksjonssykdommer, Haukeland universitetssykehus, www.helse-bergen.no/avd/tropemedisin/

15. Legathåndboken, www.legathåndboken.no 